\title{
Facilitating the Creation of Knowledge within an e-Learning Framework to Develop Critical Thinking Skills
}

\author{
Gail K. Tillman
}

\begin{abstract}
In this article I will share a self- study of an online course. The course being explored is a first year undergraduate degree course with a large student cohort. In order to provide relevant and positive student experiences, best teaching practices are constantly being sourced, critiqued and explored. Two assessment styles will be discussed such as, experiential based learning, which allows students to maximise their own learning potential and the use of discussion board as on online learning tool, which promotes a writing collaboration between student and facilitator. As part of my current Doctoral research, this paper will further demonstrate how students developed critical thinking skills using their own sense of a writing identity; they became the creators of knowledge sharing. Analysing the course feedback and outcomes revealed not only androgogical challenges and successes in cultural competence, but also how e-learning success can be achieved in developing critical thinking skills within a cultural framework for first year students. The outcome of this research will contribute to the existing knowledge on best teaching practice in online teaching and learning within a cultural framework and its implications for the future.
\end{abstract}

Index Terms-Asynchronous learning, critical thinking, cultural framework, e-learning.

\section{INTRODUCTION}

This paper will discuss the development of critical thinking skills by students undertaking the online course facilitated at The Wollotuka Institute, University of Newcastle, in semester one, 2014. The course being explored is a first year undergraduate degree course with a large student cohort. This course attracted a student cohort of over twenty two different degree disciplines. The course was facilitated online and within the Wollotuka Institute's 'cultural standards' framework. This paper forms part of my Doctoral study titled "Turn the switch on: The potential class and the search for the cultural thread". The purpose of this paper is to understand and examine how asynchronous based assessment, online discussion board and the personal reflection, succeeded to further expand and developed critical thinking skills amongst students undertaking this online course. The e-learning process played an integral part in student centered learning and embedding the cultural framework. Reference [1] believes that it is also vital for course facilitators to be aware of 'setting the tone' for their online teaching, creating student centered boundaries and create a sense of community amongst the student cohort.

Manuscript received July 30, 2014; revised October 8, 2014.

Gail K. Tillman is with the Wollotuka Institute, University of Newcastle, NSW, Australia (e-mail: gail.tillman@newcastle.edu.au).
Pedagogical teaching styles can also be effective in creating student motivation, achieving confidence and cultural competence.

Reference [2] further support this notion in that

"refashion education in a fundamental way, so that it becomes a coherent effort to initiate students into a knowledge creating culture. In this context, the internet becomes more than a desktop library and a rapid mail-delivery system. It becomes the first realistic means for students to connect with civilisation-wide knowledge building and to make their classrooms part of it."

Providing regular feedback and a presence within the course enables students to become empowered with their learning, writing and critical thinking skills and assists in the working towards becoming culturally competent practioners. The use of reflection and online discussion board as assessment allows student to articulate and rethink their own experiences [3]

\section{BACKGROUND}

The Wollotuka Institute is an Indigenous research; teaching and student support Centre and also teaches various courses within the University of Newcastle. At present, there are over 900 Aboriginal students enrolled at the university. The learning management system (LMS) Blackboard was used as a teaching tool for this online course. This is a proven effective tool for teaching and learning [4] for both students with its potential for students to view and download course content with relative ease, as well as for teachers who are able to create rich learning experiences for their students. Current evidence highlights that when using Blackboard efficiently, [4] it creates a student centered approach in achieving effective online teaching and learning.

Students are informed at the beginning of the semester that the course will be trialing new teaching and learning strategies in which they will be called upon to complete an anonymous course survey in Blackboard at the end of the semester. This allows a critique of one's teaching to occur and changes to be implemented for the next semester.

The title of the first year online course being discussed is 'Working with Aboriginal Communities'. The main objective of the course is for students to become efficient in working towards becoming a culturally safe and competent practioner within their future career. The Wollotuka Institute has a cultural standards document that provides guidelines with its courses to create and maintain Aboriginal content. The Cultural Standards [5] document on academic and research matters include: 
- The utilisation of cultural values and principles which reflect unique Aboriginal and Torres Strait Islander knowledges will contribute to the creation of a culturally safe and healthy learning environment.

- Knowledge is acquired through a culturally responsive and embedded process where the knowledge and wisdom of Elders and cultural mentors is incorporated throughout the curriculum and within classroom teaching contexts.

- All staff is recognised as conduits as well as knowledge creators for cultural based teaching as well as other knowledges appropriate to the university context.

\section{But EVERyone CAN SEe What I Write!}

The use of online discussions as an authentic learning activity is a productive way to engage adult learners. This method also encourages students to think and write critically and independently which in turn contributes to their overall personal growth in the course. According to [6] writing in an academic and cultural manner within the weekly discussion board format allowed students to develop their own identity as creators of knowledge. In order for students to succeed further in academic rigor, the course was designed so that students needed to submit their discussion board post first before they could view their peer's post and make a comment on them. As the student learns more every week their knowledge is slowly replaced from 'myth' to 'fact' in regards to cultural content and their understanding. Also included was a Week one and two practice timeframe at the beginning of the course on which students were not graded. This time frame also allowed any problems or 'troubleshooting' to be remedied. The culmination of this teaching strategy bought mixed results from the students. Initially, students could view each other's postings and this tended to encourage a form of 'laziness' in the student. This was because the student was not made to use or encouraged their critical thinking skills.

\section{WRITING ChaLlENGES}

In order to fulfill assessment requirements students needed to write a weekly post. For many, this was a daunting task that made many students fill apprehensive. There were various reasons for this: they did not trust themselves with their own academic writing skills or did not want to appear 'stupid' in front of their peers in case they made a glaring error, for example. Or perhaps some students were used to plagiarizing their posts in online courses previously and needed to continue to do that, or felt insecure themselves about being 'exposed' in an online learning environment.

In their anonymous feedback, students noted that;

- This course has drawn my attention to my weak points, such as note taking strategies and paraphrasing.

- I would prefer to view other posts to confirm that my post was on the right track.

- I was annoyed with the students who 'cheated' and posted blank discussion posts first in order to view other student's posts

- I was initially intimidated by the concept of submitting my own post first without viewing anybody else's, but it forced me to think outside the square.
- I have done online courses before and I admit, I always read others before posting my own. I never deliberately plagiarised but it would be easy to do. It forced you to think on your own first.

- It was good to read other posts firsts to make sure that you were on the right track before submitting your own. On a few occasions in this course I misinterpreted the question and therefore did not submit my best work.

- It was hard some weeks as you wonder if you have answered the questions correctly, I struggled to gain confidence to contribute.

- Honestly I did not like this method because sometimes I need to get other student's ideas to help me out in my research.

- At first it was quite nerve wracking-however, the two 'practice posts' ensured you understood and felt more comfortable and ready for week three and when the assessment commenced gaining marks.

This demonstrates that there is a need for students, in order to learn to write critically, to be able to complete their own posts in a more self-directed and independent manner. Obviously, this style of teaching will not please all students but this method is necessary if students are going to learn how to write critically in an unplagiarised and independent manner. Once students have gained the confidence of writing without being able to view other posts, their skill of writing critically will be improved greatly. However, many students still felt that they needed to view other posts as a form of emotional support.

\section{WRITING SUCCESSES}

Once students applied themselves to improving their academic writing in an unplagiarised and more original manner, their critical skills and self-confidence started to grow and develop further throughout the semester. This also altered the tone of discussions by avoiding replication of written posts. Each week became quality content filled. Students readily engaged more in the course and commented on other student's posts with a sense of renewed learning independence and 'vigor'. They are also learning to write culturally appropriate which enables them to work towards achieving cultural competence.

In their feedback obtained, students noted that;

- I thought this was brilliantly organised. It allowed us to be creative and original, without being shaped by other student's responses and ideas.

- I have 'grown' a substantial amount as a writer and as a person as a result of online discussions. It is difficult to put into words how much I have grown as a writer.

- I found that the 'post first' method created more freedom of thinking and an honest basis to every week's post that allowed us to think individually, rather than collaboratively and was effective in maximising my learning.

- I gradually learned to dig deeper and investigate further for my own answers.

- My thoughts were original and it encouraged me to do significant research. I think that this is a vital aspect of discussion board posts. 
- This method worked well to also widen the discussion. My post often covered different content or a different approach which also assisted my learning.

- It actually made people do what was required for the course without 'cheating', and for hard working people like me, it makes me feel good about putting the effort in to gain good marks.

- I take the time to research my information and I did not like the idea of others copying my research.

- It was more rewarding being able to compare your responses and see other ideas rather than your response on someone else's.

With students having to write their own posts first before viewing others, this allowed their writing to be more authentic, valid and relevant. As a result, this also meant that plagiarism was non-existent. Students had to think critically in order to complete the written task. This validates students who do undertake writing their own posts without viewing others first, also gain much more than critical writing skills. They also experience a personal self-growth, self-development and work toward being a more confident and independent learner.

\section{THE Twists AND TURNS OF A SHAKY LEARNING JOURNEY!}

Intuition is listening to the inner voice, or what describes as finding the theory you have in yourself and in the knowledge you derive from experience [3]. This is a significant factor in the personal reflection assessment which highlights the student's own personal learning journey and their growth in cultural awareness over the semester. This enabled students to critically reflect and analyze their own knowledge and their understanding of it. Strengths and weaknesses in regards to self and their own learning were also explored and critically assessed. As the learning outcomes of the course were assessed the student's development of a becoming culturally competent practioner was often exampled within their writing. Any sense of previous existing cultural baggage they once held was slowly being peeled away.

\section{ReFLECTIVE CHALLENGES}

As part of their assessment, students needed to reflect at the end of the course, on what they had learnt overall. This assists them in applying new meaning to their learning and how this knowledge may be utilized within their future careers.

In their feedback obtained, students noted that

- Not being able to get an immediate response when I was having difficulty with something.

- The biggest thing I have learned from this class is that I don't think that I would be a great online learner.

- It was completely unnecessary and time consuming. How does this assess our knowledge of the course?

- A multiple choice test would have been more appropriate assessment than a personal reflection.

- I felt that it was weird talking about my growth as I could see it throughout the posts that I was making.
I personally have a hard time talking about myself so found it difficult; however, it opened up my eyes and

This reveals that although some students were not keen to undertake online study and perhaps writing about 'themselves', there almost appeared to be an invisible 'learning barrier' that they had inadvertently created themselves. Their learning confidence within themselves appears to be 'stunted'. This further contributed to them resisting their own learning growth within the course.

\section{REFLECTIVE SUCCESSES}

In analyzing these reflective successes students learnt to become more confident and independent learners. An overall improvement in them occurred in regards to self-confidence and a learning passion within the online learning environment.

In their feedback obtained, students noted that

- Writing this personal reflection has not only had an effect on the development of my critical analysis skills, but also helped me to improve the ability of drawing a conclusion from evidence, after having constructed an argument and interpreted it.

- This was a great tool to actually be able to look back upon work and recognise unintentional growth. I have used the knowledge gained from this task to assist in my future learning journey.

- Experiencing something initially is good, but when we reflect on something it really reinforces the ideas and acts as a way to sum it all up-to see the bigger picture. I really engaged with the content and concepts presented each week, so I think that this is the first time I've really engaged with a reflection in a genuine way.

- It was a chance for me to sum up all that I had learnt, where I went wrong and where I went well. I felt very comfortable in discussing my growth and was very honest at times when looking at my work ethic.

- They should be a part of more courses. It was your own journey and I was able to reflect on how far I had come and how my knowledge and understanding had changed.

- I learned to be less dependent on the instructor and more dependent on me.

- This is where my critical thinking skills came in handy, but being an independent learner enabled the student to become a better member of the learning community.

- My greatest weakness- the inability to access information instantly became my greatest strength-my ability to become an independent learner.

- This semester has helped me address and evaluate my employability skills and in doing this I have identified what areas need improving.

- Acknowledging the feedback received for my work has been a significant factor for the development of my skills. It not only helped me to better identify my strengths and weaknesses, but also gave me self-confidence and enthusiasm, two key factors for continual improvement of one's self.

This discloses to us that there has been a powerful transformation in which the students now write and think differently and with more academic rigor. Also worth noting 
is that the student's own self-confidence increased as a result of completing this reflective assessment. Experiential based learning allowed students to maximize their own learning capacity. They engaged more readily with the course content in a more positive manner. This helps to reshape their experience and provides new meaning to the student. It is about working through and understanding beliefs, assumptions and attitudes and the role of the facilitator to create a safe learning environment for changes to occur [7]. I created this survey in Blackboard for students to reveal what worked for them and what did not. This enabled me to make changes to the course in the future. This experience has allowed my own personal growth to develop further as a teacher which has enabled me to also critically reflect on my own teaching practices.

\section{CONCLUSION}

Although the Wollotuka Institute is responsible for the strengthening and resourcing the educational journey of all of its Indigenous students, it also is committed to its students achieving a level of cultural competence [8]. This self-study has revealed solid findings in regards to factors in the teaching and learning online environment. To conclude, the student's confidence grows in aspects of their own learning and this reveals how their strengths can become their weaknesses. Once students create their own 'tools' for making sense of their writing in order to understand their own learning journey, they can then build upon this in the future. This becomes a lifelong learning skill which has been developed. Students become encouraged to investigate further for research and their own answers; this then becomes a learned critical thinking skill. Students learn to be less dependent on the online facilitator and more dependent on themselves, resulting in becoming independent, confident learners. The academic writing of the student's personal learning journey assists them to draw conclusions from evidence and how to interpret it themselves. The anonymous end of semester feedback from students allows the facilitator to not only critique their own teaching, but also implement changes to their future online courses. This enables the student to become a more valued member of the online student community by having their feedback seen as valid and constructive. Although student feedback can ultimately improve academic courses, without that valuable feedback as a learning tool for us, we, as facilitators, would not be able to implement successful changes in online courses that are needed. Therefore, the need to reflect critically upon one's self for both the student and the teacher is vital to create learning, teaching and personal growth.

\section{REFERENCES}

[1] P. Elison-Bowers, J. Sand, and S. Buchanan, "Strategies for managing large online classes," The International Journal of Learning, vol. 18, no. 2, 2011.

[2] M. Scardamalia and C. Bereiter, "Knowledge Building: Theory, pedagogy and technology," in Cambridge Handbook of the Learning Sciences, K. Sawyer, Ed., New York: Cambridge University Press, 2006, pp. 97-118.

[3] K. Pavlovich, "The development of reflective practice through student journals," HERDSA, vol. 26, no. 3, pp. 281-295, August 2007.

[4] A. Hatfield, S. Walker, M. Tambyah, and D. Beutel, "Blackboard as an online learning environment: What do teacher education staff and students think?" Australian Journal of Teacher Education, vol. 36, no. 7, pp. 1-16, July 2011.

[5] Cultural Standards, The Wollotuka Institute, The University of Newcastle, 2013, p. 15.

[6] K. Harrington, P. O'Neill, and L. Reynolds, "Using wikis and blogs to support writing development: The online evolving essay project," in Staff-Student Partnerships in Higher Education, J. Little, Ed., London Continuum International Publishing Group, 2011, p. 74.

[7] M. Stewart, "Understanding learning: Theories and critique," in University Teaching in Focus, A Learning Centered Approach, L. Hunt, D. Chalmers, Ed., Victoria. ACER Press, 2012, p. 16.

[8] G. Tillman and S. Gilbert, "Embedding - The Wollotuka Institute's cultural standards into teaching practice," presented at the WIPCE 2014 Conference, Honolulu, HI, May 20-24, 2014.

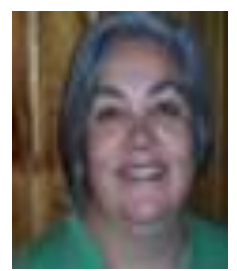

Gail K. Tillman received her master of education in adult education at the University of Technology in Sydney, Australia in 2002. She also has the bachelor of education in adult education at the University of Technology, Sydney in 2000 and the bachelor in education in secondary at the Australian Catholic University in Sydney in 2007.

She has taught in various educational areas, including tertiary, university sectors and schools. She is currently working as a lecturer at The Wollotuka Institute, University of Newcastle, NSW, Australia.

She is interested in Australian indigenous issues, including education, pedagogy and online teaching and learning as well as the 'first year experience' for higher education students. She is currently a $\mathrm{PhD}$ candidate. 